\title{
СЕПАРАТИСТИ ЧИ УКРАЇНЦІ ШЛЯХ ДО ЗГОДИ
}

Показано, що у воєнний конфлікт втягуються не лише ті, хто перебуває в зоні бойових дій чи тримає зброю в руках, а й мирні громадяни, які відчувають на собі прямий чи опосередкований вплив цих воєнних дій. Порушується проблема використання мовних кліше (наприклад, “сепаратист", "націоналіст", “вата”, “бандюки”) як інструменту спрощеного розуміння ситуації та залучення в конфлікт. Обстоюється ідея необхідності розроблення програм психологічного супроводу, реадаптації та реінтеграції учасників бойових дій і мешканців окупованих територій у мирний простір життєдіяльності суспільства. Сформульовано та описано проблематику, що має найбільший конфліктний потенціал 3 погляду формування загальноукраїнської ідентичності: 1) використання мовних маркерів; 2) неготовність пробачати, якщо в результаті воєнного конфлікту загинули близькі; 3) оцінки подій кінця 2013 - початку 2014 років; 4) ставлення до політичних лідерів РФ; 5) бачення майбутнього Донбасу. Визначено, які уявлення $\epsilon$ спільними для громадян підконтрольних та окупованих територій: негативне ставлення до воєнних дій; відсутність ненависті до пересічних громадян; незадоволеність через корумповані дії представників влади; неприпустимість мародерства; уявлення про можливий перебіг воєнного конфлікту; уявлення про роль та інтереси РФ у воєнному конфлікті. Представлено модель пошуку злагоди та порозуміння між громадянами підконтрольних і тимчасово окупованих територій, яка передбачає поетапні заходи: 1) формування спільного образу ситуації; 2) створення оптимальної моделі взаємодії; 3) оприявнення та інвентаризацію ресурсів і засобів упровадження запропонованої моделі. Підкреслюється необхідність розроблення критеріїв оцінки справедливості прийнятих рішень у різних проблемних ситуаціях. Запропоновано низку рефлексивних питань, що дають змогу зняти наявні наразі упередження щодо мешканців ОРДЛО. Зроблено висновок про необхідність розроблення програми психологічного супроводу процесів формування та розвитку загальнонаціональної ідентичності для мешканців окупованих територій.

Ключові слова: політико-правова свідомість, ідентичність, конфлікт, злагода, діалог.

\section{M. Dukhnevych}

\section{SEPARATISTS OR UKRAINIANS? WAY TO AGREE}

It is shown that the military conflict involves not only those who are in the area of hostilities or who hold weapons in their hands but also peaceful citizens who experience the direct or indirect influence of these hostilities. The emphasis is on the problem of using language cliche (for example, "separatist", "nationalist" and others) as an instrument of simplified understanding of the situation and involvement in the conflict. The idea of the necessity of developing programs of psychological support, rehabilitation, and reintegration of combatants and inhabitants of the occupied territories into the peaceful space of society's life is noted. It is formulated and described the problem with the greatest conflict potential in terms of formation of the national identity: 1) the use of language markers; 2) unpreparedness to forgive in case of relatives' lost as a result of military conflict; 3 ) evaluation of the events of the end of 2013 - beginning of 2014 ; 4) attitude towards the political leaders of the Russian 
Federation; 5) vision of Donbas future. It was defined which representations are common to the citizens of the controlled and of the occupied territories: negative attitude to military actions; no hate to ordinary citizens; dissatisfaction with the corrupt actions of the authorities; the notion of inadmissibility of looting; the ideas of possible ways of developing of a military conflict; an idea of the role and interests of the Russian Federation in a military conflict. The model of the search for consent and understanding of citizens of controlled and temporarily occupied territories is presented. The model describes 1) steps to form a common image of the situation; 2) creating an optimal model of interaction; 3 ) the need to create inventory resources and means of implementation of the proposed model. It is emphasized the need to develop the criteria for assessing the fairness of decision making in various problem situations. A number of reflexive questions are proposed which allow reducing the bias towards the inhabitants of the occupied regions of Donetsk and Luhansk. The conclusion is made on the necessity of program developing on psychological support for the processes of formation and development of national identity for inhabitants of the occupied territories.

Key words: political-legal consciousness, identity, conflict, agreement, dialogue.

Постановка проблеми. Різні джерела наводять свою статистику щодо чисельності учасників збройного конфлікту на сході України. Так, станом на листопад 2018 року близько 50 тисяч українських військовослужбовців брали участь в Операції об'єднаних сил. I це число не враховує тих, хто вже звільнився в запас чи повернувся із зони бойових дій для проходження служби в інших частинах. За даними, які наводить Левко Стек, чисельність “збройних сил” угруповань “ЛНР” і “ДНР” становить близько 35 тисяч осіб [1]. Достеменно не відомо, скільки із цих 35 тисяч є громадянами України, а скільки - громадянами інших держав. Очевидно, що мотиви, які змусили українських громадян, що проживають на Донбасі, взяти в руки зброю, різні: для когось це ідеологічні переконання, для когось до певної міри це вимушена міра, ще для когось - спосіб самоствердження і т. ін.

Якою б не була мотивація участі громадян України в збройному конфлікті, - і не важливо, по який бік від лінії розмежування, - напевно можна стверджувати тільки одне: участь у воєнних діях впливає не лише на психічні та психологічні стани самої людини, а й поширюється на стратегії іiї взаємодії з іншими людьми та державними й суспільними інституціями, викривлює уявлення про ефективні дії в проблемних ситуаціях у політико-правовій сфері, спричинює радикалізацію свідомості.

Загальновідомою є думка, що виживання в умовах воєнних дій можливе почасти лише за умови поділу на “свій” і “чужий”, тобто за умови спрощеного бачення світу. Таке “тунельне сприйняття”, поділ світу на “зрозуміле” і “незрозуміле”, “біле” і “чорне” переноситься на мирне життя і ті стосунки, що передбачають широку палітру уявлень, поглядів та сценаріїв дій та поведінки. Оформлюється нова соціальна категорія - “люди війни”, що готові зі зброєю в руках відстоювати свої переконання навіть поза межами зони воєнних дій. Частково, імовірно, це пов'язано з порушеннями процесу реадаптації та ресоціалізації тих, хто повертається із зони бойових дій. Але це справедливо лише до певної 
міри, адже різноманітні зміни свідомості можуть проявлятися незалежно від ситуації воєнних дій. У юридичній психології це так звані деформації правосвідомості.

Зрозуміло, що у воєнний конфлікт втягуються не лише ті, хто перебуває в зоні бойових дій чи тримає зброю в руках, а й мирні громадяни, які відчувають на собі прямий чи опосередкований вплив цих воєнних дій. Звісно, більшою мірою це стосується ВПО, мешканців територій поблизу лінії розмежування, родичів військовослужбовців, що перебувають нині чи перебували раніше в зоні бойових дій, ідейних опонентів, які опинилися по різні сторони від лінії розмежування. Проте навіть ті громадяни, для яких війна далеко, можуть відчути на собі наслідки воєнних дій, у тому числі й через окремі терористичні акти в різних регіонах України (підрив автомобілів у Києві, вибухи на складах боєприпасів тощо).

Напевно, найбільш яскраво залученість простих громадян у переживання ситуації воєнного конфлікту ілюструють поширені сьогодні оцінки та мовні кліше "сепаратист”, “укроп”, “націоналіст”, “вата", “фашист”, “бандюки” тощо. Саме на основі цих смислів часто вибудовується розуміння воєнного конфлікту та його перебігу тими, хто взяв у руки зброю i, що ще більше насторожує, пересічними громадянами. Використання таких мовних зворотів і штампів породжує цілий комплекс ставлень-стосунків-відносин, які обов'язково слід вивчати і враховувати під час розроблення відповідних програм психологічного супроводу, реадаптації та реінтеграції учасників бойових дій у мирний простір життєдіяльності суспільства. Очевидно, такі програми мають розроблятися і для тих, хто залишився за лінією розмежування, враховувати завдання реадаптації тих, хто в результаті воєнних дій втратив близьких або з ідеологічних, фінансових чи інших міркувань підтримував сепаратистські рухи на Донбасі. Смисл таких програм - сприяти руйнуванню настановлень типу “вороги” і “противники”, створювати базис та можливості для виникнення діалогу.

Аналіз останніх досліджень і публікацій. До певної міри вирішенню цих завдань слугують дослідження витоків і причин розвитку воєнного конфлікту (Є. Головаха, І. Кононов, І. Рущенко та І. Дубровський, І. Семиволос та ін.). Політико-правовий аспект ситуації на сході нашої країни вивчають відомі фахівці в політичній, правовій, економічній та соціальній галузях, зокрема В. Горбулін, В. Брехуненко, М. Дем'яненко, П. Гай-Нижник, С. Ільченко, В. Трегубов та ін. Значну увагу науковці приділяють проблематиці ПТСР (Т. Титаренко, Х. Турецька, С. Ніколаєнко та ін.).

Не вирішені раніше частини загальної проблеми. Наразі $\epsilon$ окремі роботи, присвячені проблематиці реінтеграції тимчасово окупованих територій в український простір, проте в цих роботах презентовано бачення більшою мірою соціальних, економічних, гуманітарних чи правових аспектів життєдіяльності громадян поблизу лінії розмежування і за нею, розглядаються проблеми ВПО, пропонуються стратегії 
психологічної роботи з постраждалими на основі медичних і психотерапевтичних методик (див., зокрема, [2; 3]). Поза увагою залишаються при цьому психологічні аспекти політико-правової ситуації та іiі наслідки для українського суспільства; бракує психологічних програм забезпечення процесів реінтеграції громад, що залишилися на окупованих територіях; недостатньо робіт, що висвітлювали б проблематику формування загальноукраїнської ідентичності.

Мета статті: презентувати найбільш і найменш конфліктні аспекти трансформацій загальноукраїнської ідентичності громадян країни, що перебувають по різні сторони від лінії розмежування, та запропонувати розробки, які могли б бути включені в програми психологічного забезпечення процесів реінтеграції мешканців Донбасу в український соціокультурний простір.

Виклад основного матеріалу дослідження. Щоб дослідити основні уявлення громадян щодо ситуації збройного протистояння на Донеччині та Луганщині, з'ясувати зміст і специфіку цих уявлень, зокрема щодо громадян, які перебувають по різні сторони лінї розмежування, ми скористалися найбільш загальними рамками дослідження. Для цього було обрано методологію якісного дослідження. Ми застосували часову тріангуляцію як процедуру підвищення надійності та валідності вимірювань, а саме: зібрані в ході дослідження дані опрацьовувалися двічі - у перші дні після переведення аудіозаписів у транскрипти і через 6 тижнів після підготовки перших аналітичних викладок та узагальнень.

За допомогою фокусованих глибинних інтерв’ю та фокус-груп ми опитували переважно молодь - студентів київських закладів вищої освіти та молодих людей, що тільки розпочинають свою професійну кар'єру (17 осіб). Представники інших соціальних груп і прошарків представлені в нашому опитуванні вибірково та значно меншою мірою, це безробітні (4 особи) та пенсіонери (2 особи). Вибірка формувалася відповідно до вимог якісної стратегії, а тому охоплювала найбільш вразливі категорії громадян з погляду залученості до політико-правової дійсності.

Поєднання інтерв’ю з фокус-групами дає змогу, з одного боку, побачити індивідуальні реакції учасників, 3'ясувати їхні погляди на проблематику, що обговорюється, а з другого боку - виявити специфіку взаємодії між учасниками дослідження та їхню реакцію на твердження інших учасників обговорення на неоднозначні, провокаційні та соціально чутливі теми.

Важливе уточнення: ми не мали змоги провести власне дослідження на тимчасово окупованих територіях. Проте враховувати погляди, настановлення та упередження, поширені серед мешканців окупованих територій, украй важливо. Тому наші аналітичні викладки базуватимуться не тільки на результатах проведених нами наукових пошуків, а й на результатах досліджень, отриманих іншими фахівцями. Зокрема, це стосується досліджень, проведених на окупованих територіях Донець- 
кої та Луганської областей. Насамперед ми будемо апелювати до досліджень, проведених у вересні 2018 року з ініціативи Українського інституту майбутнього (детальніше див. [4]).

Ми спробували узагальнити отримані нами та іншими фахівцями результати крізь призму двох фільтрів. Перший передбачав визначення суспільно чутливих тем, що найбільше провокують посилення соціальної напруженості та можуть стати на заваді пошуку порозуміння і формуванню спільного бачення шляхів вирішення актуальних завдань у ході побудови програм перспективного майбутнього. За допомогою другого фільтра ми намагалися визначити такі індикатори, які єднали б представників різних частин країни, давали б змогу формувати засади для розвитку спільного бачення в людей, що перебувають по різні сторони від лінії розмежування.

Отже, ми спробували окреслити проблематику, щэо має найбільший конфліктний потенціал для громадян підконтрольних та окупованих територій:

1. Використання мовних маркерів. Мешканці підконтрольних територій, які брали участь у нашому дослідженні, рідко використовували маркери типу “сепаратисти”, характеризуючи тих, хто залишився по інший бік від лінії розмежування. Водночас вони апелювали до тієї обставини, що 2014 року мешканці окупованих територій підтримали відокремлення та утворення “ЛНР” і “ДНР” (так звані “референдуми”). Частіше цей маркер використовується для означення тих громадян України, які беруть участь зі зброєю в руках у формуваннях “ЛДНР”. Загалом такого роду комунікативні шаблони не набули значного поширення. Можна стверджувати, що ставлення до пересічних мешканців Донбасу досить помірковане і виважене; висловлюється співчуття 3 приводу того, що ведуться бойові дії, через які страждають мирні громадяни. Натомість у лексиконі мешканців Луганщини та Донеччини широко представлені маркери “нацисти”, “націоналісти”, “западенці”, “бандерлоги" тощо; поширені міфи на кшталт "націоналістична бандерівська ідеологія", “зачистки серед мешканців Донбасу” і т. ін.

2. Громадяни, які втратили рідних і близьких у результаті воєнних дій, не готові пробачати противникам. Учасники нашого дослідження висловлювали думки, що ті, хто втратив унаслідок бойових дій не тільки домівки чи інше майно, а й близьких людей, очевидно, $є$ більш негативно налаштованими щодо учасників збройних формувань ОРДЛО. Це гуртує людей з різними політичними уподобаннями, викликає співчуття. А та обставина, що українські громадяни виступили зі зброєю в руках проти своїх співвітчизників, переживається як біль і втрата. Багато хто переконаний, що людей переповнює бажання реваншу та помсти за загибель близьких і рідних. Проте справедливе та об'єктивне розслідування всіх обставин участі наших громадян у збройному конфлікті на боці воєнізованих угруповань “ЛНР" і “ДНР” може запобігти ескалації конфлікту. 
Дослідження уявлень мешканців окупованих територій показало, що “ті мешканці “ДНР” та “ЛНР”, які втратили близьких чи домівки, навряд чи пробачать українцям, не зможуть жити ж ними в одній країні” [4]. Іншими словами, декларується готовність не пробачати, відстоювати своє бачення ситуації, свою "правду". Зрештою це може призвести до "війни правд”, коли громадяни, що мають різні погляди, різне бачення ситуації воєнних дій на сході країни та розвитку цієї ситуації, ії наслідків, будуть відстоювати свою “правду”, своє бачення справедливого розв'язання ситуації.

Природно, втрата близьких у збройному конфлікті - найбільш емоційно насичена, провокативна і конфліктна тема, що потребує розроблення та реалізації спеціальних технологій пошуку злагоди, побудови стосунків та налагодження конструктивної взаємодії між прихильниками різних сценаріїв розвитку України і майбутнього окупованих територій.

3. Оцінки подій кінця 2013 - початку 2014 років. Думки мешканців підконтрольних територій з цього питання не є однозначними. Для когось це Революція Гідності, для когось - вимушена зміна влади не зовсім легітимним способом, ще для когось - державний переворот. Останніх найменше, проте навіть сьогодні, через 5 років після початку воєнних дій, такі оцінки усе ж трапляються (детальніше див. [5, с. 62]). Мешканці ж окупованих територій ці події трактують як державний переворот (не можна виключати, що це може бути наслідком мімікрії, коли істинні уявлення приховуються або ж є результатом інформаційного впливу російських ЗМК. Крім того, такі уявлення могли нав'язуватися мешканцям Донбасу від самого початку подій на Майдані Незалежності в Києві у 2013 році. Очевидно, що це питання ще потребує свого додаткового вивчення).

4. Ставлення до політичних лідерів РФ. Якщо у мешканців окупованих територій воно $є$ переважно позитивним, особливо до В. Путіна, то в мешканців, що перебувають на підконтрольній території, таке ставлення має градацію від помірно негативного до вкрай негативного (зауважимо, що 3 огляду на неоднозначність оцінок подій 20132014 років, можливо, можуть бути й інші оцінки, проте в нашому досліджені вони не були зафіксовані).

5. Бачення майбутнього Донбасу. Респонденти, що брали участь у нашому дослідженні, виражають надії та сподівання на відновлення контролю над тимчасово окупованими територіями, відновлення кордону та повернення цих територій до складу України. Сценарії повернення окупованих територій чітко не визначені, однак акцент загалом робиться на політичному, а не на силовому розвитку подій. Досить поширені уявлення про те, що “там теж наші люди, які так само страждають від війни”. Натомість більшість учасників досліджень на окупованих територіях "розчаровані тим, що досі не входять до складу РФ, як Крим, не розуміють, чим вони відрізняються від мешканців Криму, але при цьому всіляко виправдовують Росію, наголошуючи що на даний час РФ просто не має можливості приєднати ДНР та ЛНР, але це 
питання серед нагальних та важливих для влади РФ” [4]. Найбільш бажаним для мешканців окупованих територій є сценарій входження “ЛНР" та "ДНР" до складу РФ на будь-яких умовах. Поширеними $є$ також уявлення про можливість входження до складу України за певних умов, а саме за умови іiі федералізації.

Окремо зазначимо, що серед громадян, що нині перебувають на окупованих територіях, значною мірою поширені уявлення про можливість репресій з боку чинної української влади. Вони супроводжуються різноманітними міфологемами (на кшталт “рабів для ЗСУ-шників” та ін.), які викликають страх та сприяють формуванню в мешканців окупованих територій очікувань допомоги з боку РФ.

Уявлення, що є спільними для мешканців м. Києва та жителів окупованих територій, можна узагальнити таким чином:

- ставлення до воєнних дій на території України негативне; воєнні дії загалом переживаються як трагедія, що матиме значні наслідки для майбутнього;

- переважна більшість зазначає, що не відчуває ненависті до пересічних громадян (це стосується людей по обидві сторони від лінії розмежування), що немає чого ділити 3 такими ж самими простими людьми, як вони;

- респонденти, що брали участь у нашому дослідженні, висловлюють незадоволеність через корупційні дії представників української влади. Мешканці окупованих територій також говорять про корупцію “влади” в “ДНР” і “ЛНР”. При цьому серед громадян, що нині перебувають на окупованих територіях, також досить поширені уявлення про корумпованість чинної української влади;

- відомі окремі випадки мародерства серед військовослужбовців ЗСУ та учасників збройних формувань “ЛДНР”. Це переживається як біль, втрата, відчай, сором та страх за майбутнє;

- схожі уявлення про можливий перебіг воєнного конфлікту: учасники як нашого дослідження, так і дослідження Українського інституту майбутнього дотримуються думки, що, найімовірніше, конфлікт навряд чи закінчиться протягом найближчих п’яти років. Висуваються припущення, що конфлікт розгортатиметься уповільнено; можливо, будуть спроби з боку РФ його “заморозити”, щоб реалізувати власні політичні інтереси;

- усі учасники досліджень визнають, що РФ має власні політичні інтереси, які відстоює на Донбасі. І ці інтереси не є тотожними інтересам мешканців Донеччини і Луганщини;

• усі учасники досліджень визнають, що без допомоги РФ “ДНР” i "ЛНР" не зможуть продовжити своє існування;

- негативне ставлення до В.Януковича, звинувачення його в зраді інтересів країни простежується як на підконтрольних, так і на окупованих територіях. Проте тут є певні відмінності: якщо для мешканців Донбасу В. Янукович - це “зрадник, який кинув свій народ”, то для мешканців іншої частини країни ці уявлення хоч і характерні, проте 
мають іншу інтерпретацію - його також звинувачують у зраді, тому що він “здав Крим, Донбас", а ще тому, що він “не підписав угоду про євроінтеграцію”. Отже, хоч негативне ставлення виявляють обидві групи опитаних, проте смисли цих ставлень у мешканців різних частин країни можуть різнитися.

Отже, на чому і як може будуватися процес пошуку згоди? Відомо, що в складних ситуаціях переговорів, коли кожна сторона обстоює “власну правду”, одним 3 прийомів виходу з комунікативно-когнітивних тупиків може стати звернення до того, з чим не згодні обидві сторони діалогу. Або ж до тих цінностей і думок, що поділяються всіма учасниками переговорного процесу. На нашу думку, запропоновані вище індикатори могли б стати єднальними засадами створення спільності для пошуку консенсусів та компромісів у вирішенні завдань налагодження стосунків та взаємодії між ідейними опонентами.

Результати проведених аналітичних узагальнень дають змогу в першому наближенні запропонувати модель пошуку злагоди та порозуміння між громадянами підконтрольних i тимчасово окупованих територій. Перший крок - це формування спільного образу ситуації. Для досягнення цієї мети можна використати такий алгоритм: 1) поставити питання до ситуації; 2) дати перелік характеристик ситуації, що склалася; 3) визначити, які з характеристик є ключовими; 4) 3'ясувати, що в цих характеристиках є спільного, а що - унікального для представників підконтрольних та окупованих територій; зробити акцент на тому, що об'єднує; 5) розкрити, що в ситуації, яка наразі склалась, обмежує, не дозволяє організувати ефективний діалог представників підконтрольних та окупованих територій; 6) сформулювати, що в актуальній ситуації сприяє діалогу представників підконтрольних та окупованих територій, що створює можливості для такого діалогу і як саме і т ін. Результатом має стати образ ситуації, спільний для мешканців підконтрольних та окупованих територій.

Другий крок - необхідно визначити всі можливі ресурси, які дали б змогу налагодити взаємодію та забезпечити ефективний діалог громадян, що нині перебувають по різні сторони від лінії розмежування. Результатом має стати створення оптимальної моделі взаємодії та реінтеграції тимчасово окупованих територій в український соціокультурний та політико-економічний і правовий простір. Завдання такої моделі дати відповідь на питання “як повинно бути".

Третій крок - мають бути напрацьовані ресурси та засоби впровадження запропонованої моделі. Ще одним результатом може стати перелік ризиків упровадження запропонованої оптимальної моделі взаємодії та система важелів протидії таким ризикам.

Не менш важливо також розробити критерії оцінки справедливості прийнятих рішень у тих чи тих проблемних ситуаціях та систему процедурних впливів щодо тих, хто буде порушувати прийняті домовленості та рішення. 
На нашу думку, така групова робота по впровадженню моделі пошуку злагоди та порозуміння між громадянами підконтрольних $\mathrm{i}$ тимчасово окупованих територій має вестися на кількох рівнях: на рівні пересічних громадян, що на цей час опинилися по різні сторони від лінії воєнних дій; на рівні окремих територіальних адміністрацій та інститутів громадянського суспільства і на рівні державних структур, що мають забезпечувати процес реінтеграції тимчасово окупованих територій. А оскільки, найімовірніше, представники влади тимчасово окупованих територій, які безпосередньо не мали стосунку до ведення бойових дій, будуть амністовані, то долучення їх як агентів впливу до процесу таких обговорень цілком природне.

I ще одне. Очевидно, спеціальним завданням має стати розроблення проблематики психологічного забезпечення зняття упереджень щодо мешканців ОРДЛО. Серед засобів можна назвати групові дискусії для зміни ставлення до громадян, які з тих чи інших причин залишилися по інший бік лінії розмежування, та учасників незаконних збройних формувань, які не здійснювали воєнних злочинів. Як одну з тем для таких дискусій можна запропонувати тему “сепаратизм”. Обговорення може вестися, зокрема, з урахуванням таких індикаторів:

- Чому (хто такі) сепаратисти? Що ви вкладаєте в це слово?

- Як ви вважаєте, якою була мотивація участі наших громадян у збройних формуваннях на території ОРДЛО?

- Що потрібно враховувати під час діалогу з представниками збройних формувань на території ОРДЛО?

- Які упередження та стереотипи можуть завадити вам почути іншу сторону?

- Що може допомогти вам вести з діалог з українцями, які раніше брали участь у збройних формуваннях ОРДЛО?

- Що вам потрібно зробити (врахувати), аби забезпечити можливість діалогу з представниками ОРДЛО?

- Що потрібно робити, аби забезпечити можливість діалогу мешканців України з тими нашими громадянами, які наразі перебувають на окупованих територіях?

Висновки. Наразі з усією очевидністю постає потреба в розробленні програми психологічного супроводу процесів формування та розвитку загальнонаціональної ідентичності, особливо для мешканців окупованих територій. Наявна поляризація (“ми ближче до Росії” “вони западенці”) частково може бути знята за рахунок групових обговорень, у тому числі й у запропонованому нами форматі, а також завдяки трансляції досвіду та результатів таких обговорень через спеціальних агентів впливу громадського та державного секторів. Презентована модель пошуку злагоди між громадянами підконтрольних і тимчасово окупованих територій може стати тією рамковою умовою, що дасть змогу за допомогою психологічних інструментів організувати діалоги 3 пошуку злагоди між мешканцями різних частин країни. 
Перспективи подальших розвідок ми вбачаємо в необхідності створення відповідних психологічних засад для розроблення проблематики громадянської солідарності, аби інтегрувати людей $з$ різними ідентичностями для побудови і реалізації програм спільного майбутнього та мінімізувати можливі негативні психологічні наслідки, пов'язані 3 воєнними діями й агресією РФ на території України.

\section{Список використаних джерел}

1. Стек, Л. (2018). Арсенал “ЛДНР”. Як виглядає “армія” бойовиків на п'ятому році війни. Взято 3 https://www.radiosvoboda.org/a/donbass-realii/29413588.html.

2. Гібридна війна на Сході України в міждисциплінарному вимірі: витоки, реалії, перспективи реінтеграчіï (2017). Старобільськ: ДЗ “ЛНУ імені Тараса Шевченка".

3. Стратегії трансформації і превенції прикордонних конфліктів в Україні. Збірка аналітичних матеріалів (2015). Львів: Галицька видавнича спілка.

4. Фокус-групи “Думки та настрої жителів окупованих територій” (2018). Взято 3 https://www.uifuture.org/publications/reports/24336-dumky/ta/nastroi/ jyteliv/okupovanych/terytoriy.

5. Консолідація украӥнського суспільства: иляхи, виклики, перспективи. Інформачійно-аналітичні матеріали до фахової дискусії 16 грудня 2016 р. Взято 3 http://www.razumkov.org.ua/images/Material_Conference/12_16_201 6/Identi-2016.pdf.

\section{References}

1. Stek, L. (2018). Arsenal "LDNR". Yak vyhliadaie "armiia" boiovykiv na piatomu rotsi viiny [Arsenal "LDPR". What does the "army" of militants look like during the fifth year of the war?]. Retrieved from https://www.radiosvoboda.org/a/ donbass-realii/29413588.html (ukr).

2. Hibrydna viina na Skhodi Ukrainy v mizhdystsyplinarnomu vymiri: vytoky, realii, perspektyvy reintehratsii [Hybrid War in the East of Ukraine in the Interdisciplinary Dimension: Origins, Realities, Prospects for Reintegration] (2017). Starobilsk: Publishing Hose of the Lugansk National University Taras Shevchenko (ukr).

3. Stratehii transformatsii i preventsii prykordonnykh konfliktiv v Ukraini. Zbirka analitychnykh materialiv [Strategies for Transformation and Prevention of Border Conflict in Ukraine. Collection of analytical materials] (2015). Lviv: Galician Publishing Union (ukr).

4. Fokus-hrupy "Dumky ta nastroii zhyteliv okupovanykh terytorii" [Focus groups "Thoughts and mood of the inhabitants of the occupied territories"] (2018). Retrieved from https://www.uifuture.org/publications/reports/24336-dumky/ta/ nastroi/jyteliv/okupovanych/terytoriy (ukr).

5. Konsolidatsiia ukrainskoho suspilstva: shliakhy, vyklyky, perspektyvy. Informatsiinoanalitychni materialy do fakhovoi dyskusii 16 hrudnia 2016 [Consolidation of Ukrainian society: ways, challenges, perspectives. Information and analytical materials for the Professional discussion December 16, 2016]. Retrieved from http://www.razumkov.org.ua/images/Material_Conference/12_16_2016/Identi2 016.pdf (ukr). 